\section{PENELITIAN PENGGUNAAN MINAREX SEBAGAI BAHAN PELUNAK DALAM PEMBUATAN KOMPON KARET SOL KARET CETAK}

\section{Oleh : Emiliana K, Murwati}

\section{ABSTRACT}

The objective of this research is to use Minarex oil as a softener in making rubber sole compound and to know the optimal of formulation. The research applied Minarex type 3 with four kinds of A, B, C, D and with variation 5 parts. 6 parts and 7 parts. Data analysed using Statistic Method with Completely Randomized Design and Split Plot Design. The results of this study showed that all kind of Minarex oils could be used to softener in making rubber sole compound and fulfilled the spesification of SNI 0778 - 89 - A, "Sol Karet Cetak". The optimal of formulation to Minarex type 3 was Minarex C with application 7 parts.

\section{INTISARI}

Penelitian ini bertujuan untuk memanfaatkan Minarex sebagai bahan pelunak dalam pembuatan kompon karet untuk sol karet cetak dan untuk mengetahui formula yang optimal. Dalam penelitian ini digunakan Minarex tipe 3 dengan jenis A, B, C, D dan dengan variasi jumlah 5 bagian, 6 bagian dan 7 bagian. Analisa data menggunakan Metode Statistik Completely Randomized Design (CRD) dan Split Plot Design. Hasil penelitian menunjukkan bahwa semua jenis Minarex A, B, C dan D dapat digunakan sebagai bahan pelunak pada pembuatan kompon sol karet cetak dan semua kombinasi memenuhi persyaratan SNI 0778 - 89 - A, "Sol Karet Cetak". Formula optimal dicapai oleh Minarex C tipe 3 dengan variasi jumlah Minarex 7 bagian.

\section{PENDAHULUAN}

Karet mentah adalah bahan yang keras dan liat, dengan perlakuan panas maka akan menjadi lunak dan jika didinginkan menjadi keras, jika ditarik menadi panjang dan tidak kembali setelah dilepas, sebab karet tersebut belum meagalami vulkanisasi.

Majalah Barang Kulit, Karet dan Plastik
Vulkanisasi adalah proses pemanasan campuran karet dengan belerang sehingga menyebabkan sifat karet menjadi kuat dan elastis, lebih tahan terhadap suhu rendah dan tinggi dan mudah dibentuk sesuai dengan yang diinginkan.

Untuk mendapatkan karet yang tahan terhadap panas dan dingin, minyak dan sebagainya , perlu mencampurkan bahan-bahan lain kedalam karet. Proses pencampuran tersebut disebut "Compounding" atau pembuatan kompon karet.

Setelah diperoleh kompon karet, kemudian dicetak dalam bentuk yang diinginkatt dan divulkanisasi pada subu dan waktu tertentu (5). Komposisi kompon karet berbeda-beda tergantung pada tujuan pembuatan barang jadinya. Bahan untuk pembuatan kompon terdiri dari 2 bagian yaitu bahan baku karet (karet alam atau sintetis) dan bahan-bahan pembantu. Bahan-bahan pembantu atau bahanbahan kimia yang digunakan ada bermacam-macam jenis dan fungsinya. Softener atau bahan pelunak adalah merupakan salah satu bahan kimia yang digunakan dalam pembuatan kompon karet yang berfungsi untuk memberikan efek plastisitas dan memudahkan penyatuan bahan pengisi $(2,4)$.

Ada bermacam-macam bahan pelunak diantaranya parafin oil, naphthenic oil, aromatic oil, vegetable oil dan synthetic iners (4). Minarex adalah jenis minyak aromatik produksi PT Pertamina yang diperoleh dari hasil samping pengolahan minyak bumi (3) dan merupakan produk baru yang dihasilkan oleh kilang minyak unit Pengolahan Pertamina di Cilacap.

Ada 4 jenis Minarex yang dihasilkan yaitu jenis $A, B, C$ dan $D$, masing-masing terdiri dari tipe 2 dan 3 . Hasil samping tersebut diperkirakan dapat digunakan sebagai bahan pelunak pada pembuatan sol karet cetak. Dalam penelitian ini digunakan Minarex dengan tipe 3.

\section{MATERI DAN METODA}

\section{Materi Penelitian}

\section{Bahan}

a. Bahan baku : Rubber Smoke Sheet (RSS)

b. Bahan tambahan ("ingredient"):

- Bahan penggiat : $\mathrm{ZnO}$, asam stearat

- Bahan pelunak : Minarex tipe 3 dengan jenis A,B,C dan D

- Bahan pengisi : karet riklim, karbon hitam

- Bahan pencepat : MBT, MBTS, dan TMT

- Anti oksidan : PBN

- Bahan pemvulkanisasi : sulfur

Vol. X No. 20 Tahun 1994/1995 
a. Neraca analitis

b. Two roll mill

c. Cetakan slab

d. Hydraulic

d. Hydraulic press

e. Stop watch

Formula yang digunakan dalam penelitian ini adalah sebagai berikut :

$\begin{array}{lrl}\text { RSS } & 100 \text { bagian } \\ \text { Karet riklim } & 30 \text { bagian } \\ \text { ZnO } & 3 \text { bagian } \\ \text { Carbon black } & 60 \text { bagian } \\ \text { Minarex A,B,C dan D } & 5,6,7 \text { bagian } \\ \text { Asam stearat } & 2 \text { bagian } \\ \text { PBN } & 1 \text { bagian } \\ \text { MBT } & 0,5 \text { bagian } \\ \text { MBTS } & 0,5 \text { bagian } \\ \text { TMT } & 1 \text { bagian } \\ \text { Sulfur } & 2 \text { bagian }\end{array}$

Sulfur

etode Penelitian

Proses komponding/pembuatan kompon

mbuatan kompon dengan menggunakan mesin penggiling karet terbu- ka wo roll mill) pada suhu giling $60-70^{\circ} \mathrm{C}$, sebanyak 12 kali komponding.

Pengujian curing time untuk mengetahui tingkat kematangan kompon pada ktu dan suhu yang optimum. Waktu dan suhu untuk mematangkan kompon i adalah 4 menit dan suhu optimumnya $150^{\circ} \mathrm{C}$ dengan tebal $3 \mathrm{~mm}$.

Pembuatan slab dengan menggunakan alat Hydraulic press, dengan kondisi oses;

hu $150^{\circ} \mathrm{C}$, tekanan $100 \mathrm{~kg} / \mathrm{cm}^{2}$, waktu 4 menit (tebal $3 \mathrm{~mm}$ )

Pengujian sifat-sifat fisis kompon.

ngujian sifat-sifat fisis kompon dilakukan terhadap sifat tegangan putus, pernjangan putus, ketahanan sobek, kekerasan, perpanjangan tetap, bobot jenis, tahanan kikis dan ketahanan retak lentur sesuai sara uji SNI. 0778 - 1989 - A, Karet Cetak.

Analisa hasil uji

enggunakan Metode Statistik Completely Randomized Design (CRD) kemuan dilanjutkan dengan analisa Split Plot Design.

\section{Hasil Penelitian :}

Hasil Penelitian berupa data hasil pengujian sifat fisika dari 4 macam kompon sol karet cetak (A,B,C dan D) yang meliputi tegangan putus, perpanjangan putus, ketahanan sobek, kekerasan, perpanjangan tetap, bobot jenis, ketahanan kikis dan ketahanan retak lentur. Data hasil pengujian kemudian dievaluasi secara statistik dengan metode CRD dan rekapitulasi hasil pengujian dapat dilihat pada tabel hasil uji rata-rata sifat fisis kompon sol karet cetak yang terdapat pada lampiran.

\section{Pembahasan :}

Dari data hasil pengujian sifat fisika seluruh kompon sol karet cetak menunjukkan, bahwa semua hasil uji memenuhi persyaratan SNI. 0778 - 1989 - A, Sol Karet Cetak.

Dengan demikian semua jenis Minarex A,B,C dan D tipe 3 dengan variasi jumlah 5,6 dan 7 bagian dapat digunakan sebagai bahan pelunak dalam pembuatan kompon sol karet cetak, hal ini sesuai dengan teori yang dikemukakan dalam pustaka $(3,4)$ bahwa bahan pelunak yang digunakan dalam pembuatan kompon karet diantaranya adalah golongan aromatik dan Minarex A,B,C dan D tipe 3 adalah jenis minyak aromatik produksi PT Pertamina yang diperoleh dari hasil samping pengolahan minyak bumi.

Dari hasil analisa CRD diperoleh hasil bahwa nilai optimal Minarex $A, B, C$ dan $D$ tipe 3 adalah sebagai berikut :

Minarex A;

Nilai optimal tegangan putus pada variasi jumlah 6 bagian $\left(190,77 \mathrm{~kg} / \mathrm{cm}^{2}\right)$, perpanjangan putus 6 bagian $(275,57 \%$ ), kekerasan 6 bagian ( 70 shore A), ketahanan sobek 7 bagian $\left(116,95 \mathrm{~kg} / \mathrm{cm}^{2}\right)$, Perpanjangan tetap 5 bagian $(1,67 \%)$, bobot jenis 7 bagian $\left(1,07 \mathrm{~g} / \mathrm{cm}^{3}\right)$ dan ketahanan kikis 5 bagian $\left(0,43 \mathrm{~mm}^{3} / \mathrm{kgm}\right)$. Minarex B;

Nilai optimal tegangan putus pada variasi jumlah 6 bagian $\left(237 \mathrm{~kg} / \mathrm{cm}^{2}\right)$, per. Nilai optimal tegangan putus pada variasi juman 6 bagian $(237 \mathrm{~kg} / \mathrm{cm}$ ), ketahanan sobek 7 bagian $\left(103,74 \mathrm{~kg} / \mathrm{cm}^{2}\right)$, perpanjangan tetap 7 bagian $(2,53 \%)$, bobot jenis 7 bagian $\left(1,03 \mathrm{~g} / \mathrm{cm}^{3}\right)$ dan ketahanan kikis 7 bagian $\left(0,20 \mathrm{~mm}^{3} / \mathrm{kgm}\right)$ Minarex C;

Nilai optimai tegangan putus pada variasi jumlah 5 bagian $\left(191,03 \mathrm{~kg} / \mathrm{cm}^{3}\right)$, perpanjangan putus 5 bagian ( $300 \%$ ), kekerasan 7 bagian ( 76 shore A), ketahanan panjangan putus 5 bagian $\left(30 \mathrm{C}^{2} \%\right.$ ), kekenangan tetap 7 bagian $(1,2 \%)$, bobot jenis 7 bagian $\left(1,10 \mathrm{~g} / \mathrm{cm}^{3}\right)$ dan ketahanan kikis 7 bagian $\left(0,25 \mathrm{~mm}^{3} / \mathrm{kgm}\right)$.

Vol. X No. 20 Tahun 1994/1995 
Minarex D;

Nilai optimal tegangan putus pada variasi jumlah 6 bagian $\left(176,7 \mathrm{~kg} / \mathrm{cm}^{2}\right)$, perparjangan putus 5 bagian $(302,32 \%)$, kekerasan 7 bagian ( 73 shore $A)$, ketahanan sobek 6 bagian $\left(129,66 \mathrm{~kg} / \mathrm{cm}^{2}\right)$, perpanjangann tetap 5 bagian $(2 \%)$, bobot jenis 5 bagian $\left(1,05 \mathrm{~g} / \mathrm{cm}^{3}\right)$ dan ketahanan kikis 5 bagian $\left(0,26 \mathrm{~mm}^{3} / \mathrm{kgm}\right)$. Dari kenyataan tersebut maka distribusi nilai optimal dicapai pada penggunaan Minarex 7 bagian. Hal ini disebabkan karena pada penggunaan Minarex 7 bagian akan diperoieh suatu campuran karet yang plastis sehingga memudahkan dalam pencampuran bahan lain kedalam karet.

Sedangkan hasil analisa Split Plot Design, nilai optimal tegangan putus dicapai Minarex B, uji perpanjangan putus dan ketahanan kikis oleh Minarex C, bobot jenis dicapai Minarex D, ketahanan sobek dan perpanjangan tetap oleh Minarex

Dari hasil analisa of variance terlihat bahwa Minarex A tidak berbeda nyata de. ngan Minarex C, sehingga dari kenyataan tersebut diatas berarti distribusi nilai optimal dicapai pada penggunaan Minarex C.

Dengan demikian nilai optimal dicapai oleh formula yang menggunakan Minarex $C$ dengan variasi 7 bagian dan kompon karet tersebut mempunyai kualitas yang lebih baik dibandingkan dengan formula lainnya.

\section{KESIMPULAN}

1. Minarex untuk semua jenis $A, B, C$ dan $D$ tipe 3 dapat digunakan sebagai bahan pelunak dalam pembuatan sol karet cetak dan untuk semua variasi jumlah Minarex memenuhi persyaratan SNI. 0778-89-A, Sol Karet Cetak.

2. Formula optimal untuk Minarex tipe 3 adalah Minarex jenis $\mathrm{C}$ dengan variasi jumlah Minarex 7 bagian.

\section{DAFTAR PUSTAKA}

1. Departemen Perindustrian, SNI.0778 - 89 - A, Sok Karet cetak.

2. Harry Baron, 1948, Modern Rubber Chemistry, New York, USA.

3. Khrishna SB dan Soemadi A, 1990, Studi perbandingan Penggunaan Processing oil Pertamina dan Dutrex sebagai minyak Proses dalam pembuatan telapak ban dan bantalan jembatan, Proceeding Lokakarya Processing oil, PPM Petrokimia Pertamina, Jakarta 27 - 28 Februari 1990.

\section{Roop Nagar Delhi, Rubber Technology and Manufacture}

5. Suwarti Suseno, 1990 Memanfaatkan Bahan Pembantu Produk Dalam Negeri untuk Industri Karet, Proceeding Lokakarya Processing ooil, PPM Petrokimia Pertamina, Jakarta 27 - 28 Februari 1990.

Tabel hasil uji rata-rata sifat fisis kompon sol karet cetak

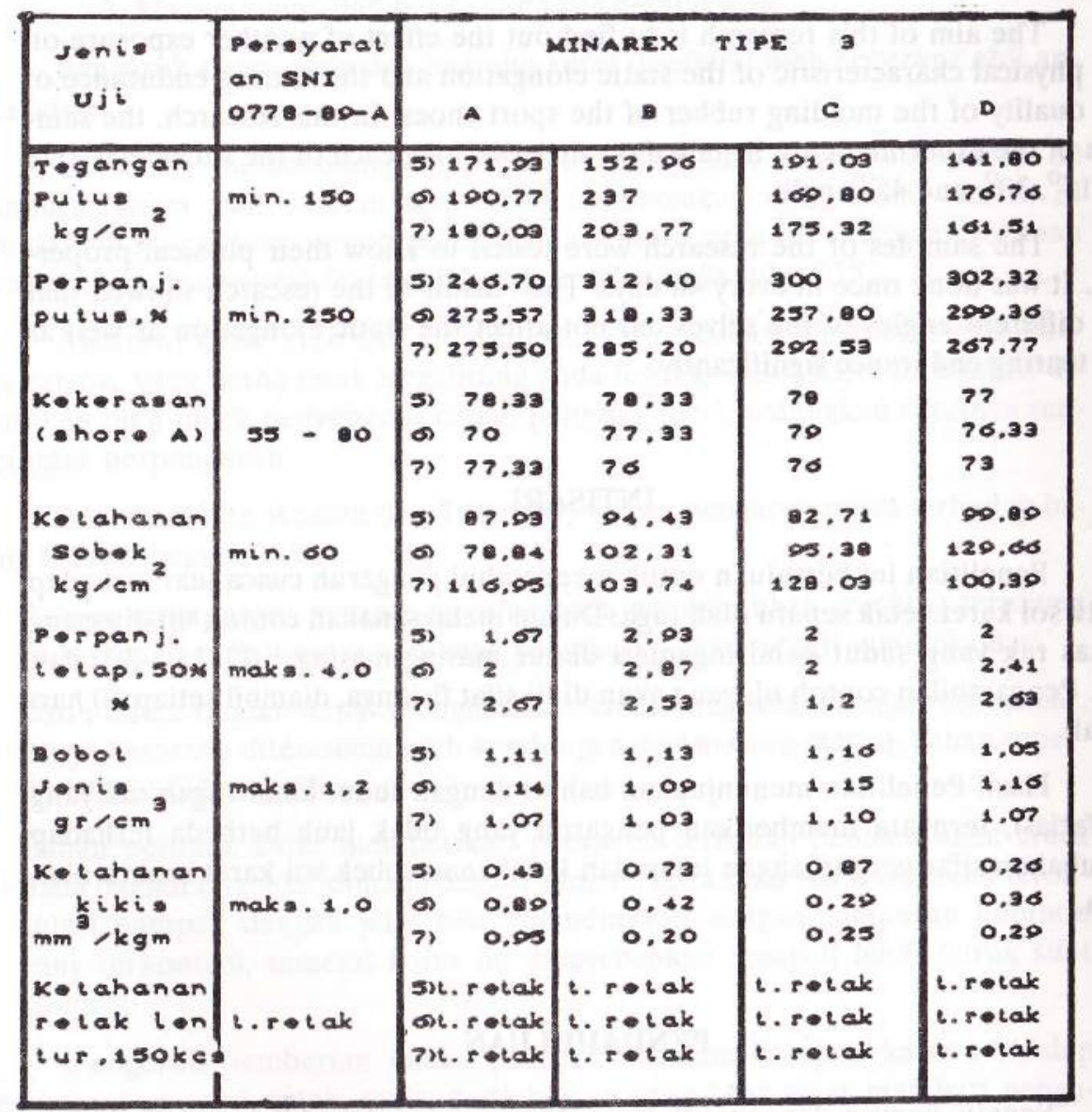

Vol. X No. 20 Tahun 1994/1995 